\title{
MODELING OF THE PROCESS OF SELECTED FIRE SIGNALING SYSTEMS
}

\author{
Jacek PAŚ ${ }^{1}$, Tomasz KLIMCZAK ${ }^{2}$ \\ ${ }^{1}$ Military University of Technology, Faculty of Electronic, Institute of Electronic Systems, Division of \\ Electronic Systems Exploitations, ul. gen. S. Kaliskiego 2, 00-908 Warsaw, Poland, jacek.pas@ @at.edu.pl \\ ${ }^{2}$ The Main School of Fire Service, Warsaw, ul. Juliusza Słowackiego 52/54, 01-629 Warsaw, Poland, \\ tklimczak@sgsp.edu.pl
}

\begin{abstract}
The article presents a selected model of the operation process of the fire system (FSS). The developed fire scenario for the selected building object is possible for practical implementation only with the use of an appropriate functional structure FSS and technical devices from which the system is built with the appropriate reliability and technical parameters. Practical implementation of FSS in a transport facility is the use of elements, devices, fire panels, detectors, etc., which form a specific connection structure. The use of appropriate technical solutions in the system - redundancy, booking and the principle of safe damage causes that FSS has an optimal structure in terms of reliability. The article presents the selected technical structure of the FSS, which was described by means of the exploitation process graph, taking into account the actual damage intensities and the renewal times for selected devices included in the system. A constant intensity of damage was assumed in the FSS operation process due to the initial aging of individual devices that takes place in the production plant. The development of a model of exploitation process for selected operational states and a computer simulation of a selected FSS enables determination of reliability indicators.
\end{abstract}

Keywords: reliability, fire alarm systems, operation, model

\section{MODELOWANIE PROCESU EKSPLOATACJI WYBRANEGO SYSTEMU SYGNALIZACJI POŻAROWEJ}

\section{Streszczenie}

W artykule przedstawiono wybrany model procesu eksploatacji systemu sygnalizacji pożarowej (SSP). Opracowany scenariusz pożarowy dla wybranego obiektu budowlanego możliwy jest do realizacji tylko z zastosowaniem odpowiedniej struktury funkcjonalnej SSP i urządzeń technicznych z których zbudowany jest system. System powinien się posiadać odpowiednie parametry niezawodnościowo-techniczne. Realizacja praktyczna SSP w obiekcie to wykorzystanie elementów, urządzeń, central sygnalizacji pożarowej, czujek, itd., które połączone instalacją tworzą określoną strukturę o wyznaczonych relacjach przez projektanta. Stosowanie odpowiednich rozwiązań technicznych w systemie - tj. rezerwowania i zasady bezpiecznego uszkodzenia powoduje iż SSP posiada optymalną strukturę pod względem niezawodności. W artykule przedstawiono wybraną strukturę techniczną SSP, którą opisano za pomocą grafu procesu eksploatacji uwzględniając rzeczywiste intensywności uszkodzeń i czasy odnowy dla wybranych urządzeń które wchodzą w skład systemu. Założono stałą intensywność uszkodzeń w procesie eksploatacji SSP ze względu na wstępne starzenie poszczególnych urządzeń które ma miejsce w zakładzie produkcyjnym. Opracowany model procesu niezawodnościowo-eksploatacyjnego dla wybranych stanów i symulacja komputerowa w wybranej aplikacji umożliwiają wyznaczenie odpowiednich wskaźników użytkowania SSP.

Słowa kluczowe: niezawodność, systemy sygnalizacji pożarowej, eksploatacja, model

\section{INTRODUCTION}

Transportation sites use widely understood safety systems, in particular fire signalling stations (FSS), sound alarm systems (SAS), smoke extraction systems and fixed extinguishing equipment (FEE), both water - and gas - based. The listed safety systems monitor all premises, e.g. railway switching stations, switchgears, teletechnical containers, railway stations and platforms $[3,5,8,13,17,23,25]$. During this age of technological progress, every investment results in changes of railway sites, through the use of modern fire safety systems $[1,11,15,16,22,26]$. These include mainly FSSs integrated with many electronic safety systems - e.g. CCTV, access control, technical installations, as well as with building management systems (BMS). According to Annex 1 to the Regulation of the European Parliament and of the Council (EU) no. 305/2011 of 9.03.2011, entire buildings and their individual parts must be usable according to their intended use. According to Annex 4 to this Regulation, fixed extinguishing equipment and fire detection and signalling products are qualified in the group with code 10 and are considered as construction products 
because of their functions, important from the point of view of safety. Application of the given system depends on the legal requirements, the fire scenario to be executed. It also depends on legal requirements applicable to the protected site, the accepted scope of protection and requirements to be met by the installation. Depending on the design, configuration and the type of linear elements used Fig. 1, several different types of fire signalling systems are distinguished [5,8,13,17,23,24].

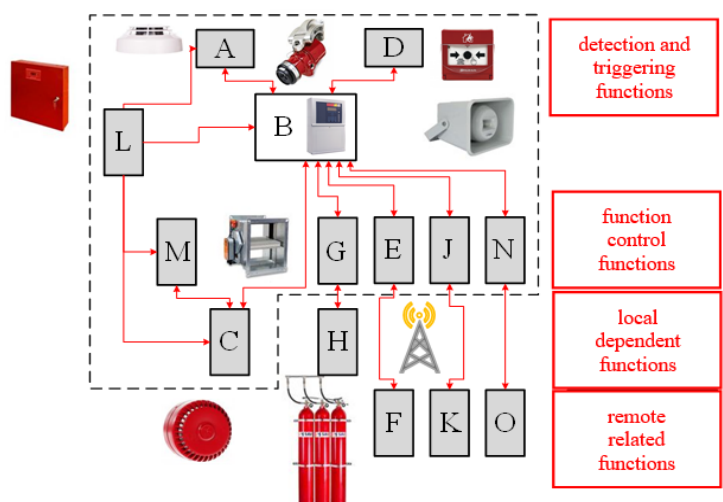

Fig. 1. FSS and related systems, functions and devices, where: A - automatic fire detection function; $\mathrm{B}$ - operation and signalling function; $\mathrm{C}$ - fire alarm function; $\mathrm{D}$ - manual initiation function; $\mathrm{E}$ - fire alarm transmission; $\mathrm{F}$ - fire alarm reception function; $\mathrm{G}$ - fire protection or fire-fighting system operating device., $\mathrm{H}$ - fire protection device or fire-fighting system; J - damage signal transmission function; $\mathrm{K}$ - damage signal reception function; $\mathrm{L}$ - power supply; $\mathrm{M}$ - alarm announcement control and signalling function; $\mathrm{N}$ - auxiliary input and output function; $\mathrm{O}$ - auxiliary management function

The FFS type installed at transportation site influences their division into surveillance areas. The surveillance areas should also be specified depending on the fire hazard present therein, requiring thorough analysis of the FFS designer. Figs. $2-4$ below present selected, representative FFS configurations used at transportation sites. The accuracy of fire source indication by the alarm station depends on the FFS used. On the other hand, the fire location accuracy requirement (room no., sensor no., ROP no., etc.) is a FFS type selection criterion - concentrated, distributed or mixed types $[3,5,8,13,23,24]$.

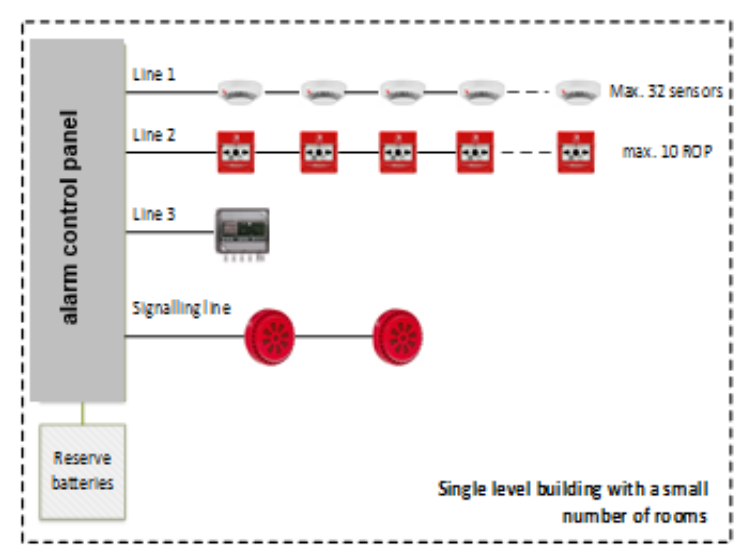

Fig. 2. Concentrated FSS with open monitoring lines, without a connection to a Fire Brigade notification system [own study]

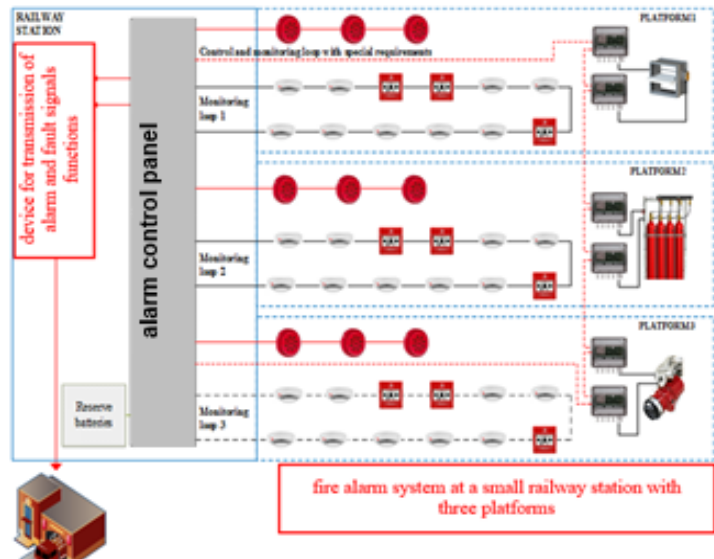

Fig. 3. Concentrated FSS with open, addressed monitoring lines at a railway station with three platforms [own study]

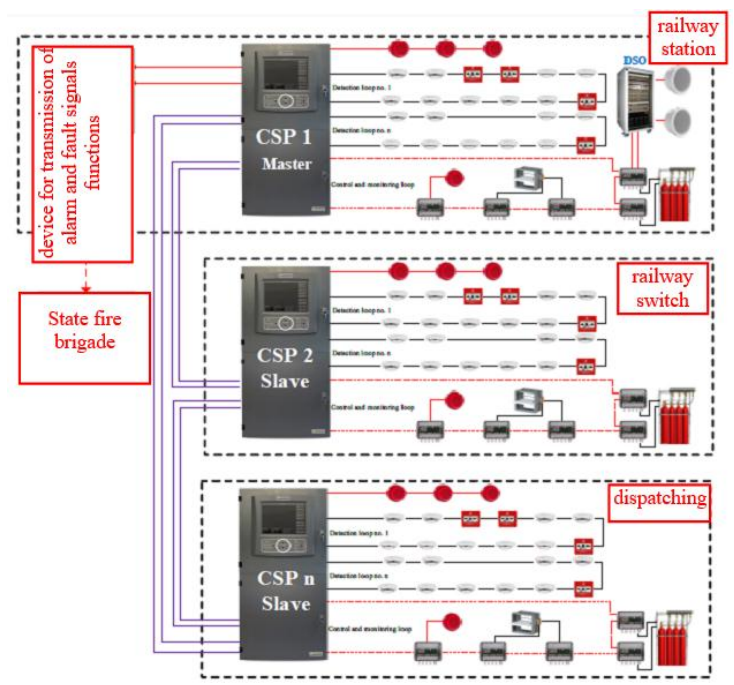

Fig. 4. A diagram presenting a distributed FFS at a vast site [own study]

\section{CONCENTRATED SYSTEM WITH A SURVEILLANCE LOOP, COINCIDING SENSOR SYSTEM AND A SIGNALLING LINE WITH A SOUND SIGNALLING DEVICE}

Fig. 5 presents a concentrated FFS using an addressed fire signalling station (FSS) with a single surveillance loop line. The line is provided with fire sensors, operating (2-warning sensor coincidence). A sound signalling device has also been installed in the surveillance line. Sensors (C1 and C2) and (C3 and C4) monitor separate premises, i.e. configuration-separated surveillance areas. Once a fire sensor is activated within the surveillance area, this sensor is initially deleted and an initial alarm is signalled in the FSS. If the deleted sensor is activated again within the pre-programmed coincidence time and another sensor becomes active in the same surveillance area, the FSS signals 
the II stage alarm, according to the pre-set alarming mode.

If the second sensor is not activated, the FFS shall deem the activation of the $\mathrm{C} 1$ sensor as false alarm and returns to the surveillance mode, deleting the initial alarm status $[2,6,10,13,15,19,23]$. The fire alarm signal should clearly specify the fire hazard and may not be caused by false factor (false alarm). Thus, two sensors were installed at the required, single surveillance sensors assigned to individual premises (areas), programmed in a coinciding system. Thus, the system is made resistant to false alarms and does not engage onduty services (e.g. alarm signal, stopping railway traffic, etc.). Damage to any of the coinciding systems decreases the functional potential of the entire FSS. Such a decrease of the functional potential of the given FSS may be improved by electronically changing the sensitivity settings of the given fire sensor from the coinciding system.

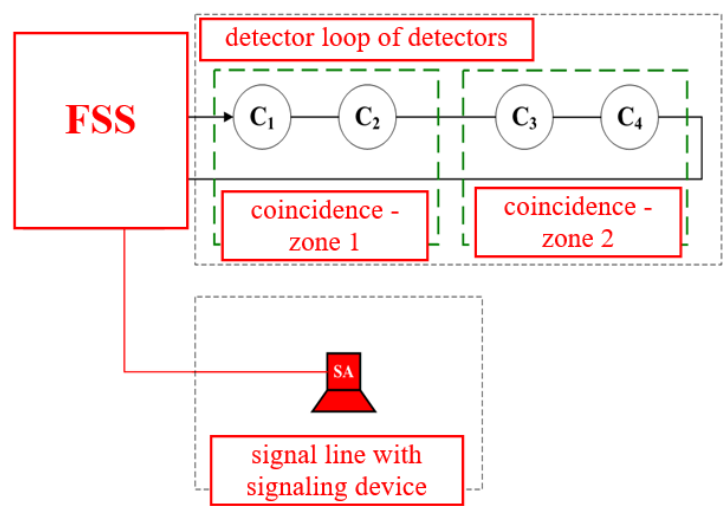

Fig. 5. A concentrated FSS with a loop-type surveillance line provided with fire sensors operating in a coinciding system (2-sensor coincidence), and a signal line with a sound signalling device.

With the knowledge of the operators, related to the sensor damage and increased sensitivity of the second sensors, the operators will be faster informed about a stage I alarm - Fig. 5. A functional and reliability analysis of a concentrated FSS is presented in Fig. 6. The explanation of the variables used in the Fig. 6 is included in the further part of the paper.

The FSS presented in Fig. 6 may be described using Kołmogorow-Chapman equations (1)

$$
\begin{aligned}
& R_{0}^{\prime}(t)=-\left(\lambda_{S A}+\lambda_{C S P}\right) \cdot R_{0}(t)-\lambda_{1} \cdot R_{0}(t)+\left(\mu_{S A}+\mu_{C S P}\right) \cdot Q_{B}(t)+\mu_{1} \cdot Q_{Z B A 1}(t) \\
& Q_{Z B A 1}^{\prime}(t)=-\lambda_{11} \cdot Q_{Z B A 1}(t)-\mu_{1} \cdot Q_{Z B A 1}(t)-\lambda_{2} \cdot Q_{Z B A 1}(t)+\mu_{11} \cdot Q_{Z B A 1}(t)+ \\
& +\mu_{2} \cdot Q_{Z B A 2}(t)+\lambda_{1} \cdot R_{0}(t) \\
& Q_{Z B A 11}^{\prime}(t)=-\mu_{11} \cdot Q_{Z B A 11}(t)+\lambda_{11} \cdot Q_{Z B A 1}(t) \\
& Q_{Z B A 2}^{\prime}(t)=-\lambda_{22} \cdot Q_{Z B A 2}(t)-\mu_{2} \cdot Q_{Z B A 2}(t)-\lambda_{3} \cdot Q_{Z B A 2}(t)+\mu_{22} \cdot Q_{Z B A 22}(t)+ \\
& +\mu_{3} \cdot Q_{B}(t)+\lambda_{2} \cdot Q_{Z B A 1}(t) \\
& Q_{Z B A 22}^{\prime}(t)=-\mu_{22} \cdot Q_{Z B A 22}(t)+\lambda_{22} \cdot Q_{Z B A 2}(t) \\
& Q_{B}(t)=-\left(\mu_{S A}+\mu_{C S P}\right) \cdot Q_{B}(t)-\mu_{3} \cdot Q_{B}(t)+\lambda_{3} \cdot Q_{Z B A 2}(t)+ \\
& +\left(\lambda_{S A}+\lambda_{C S P}\right) \cdot R_{0}(t)
\end{aligned}
$$

where: - denotes the coinciding system I, - denotes the coinciding system II.

Assuming the baseline conditions (2):

$$
R_{0}(t)=1
$$

$Q_{Z B A 1}(0)=Q_{Z B A 11}(0)=Q_{Z B A 2}(0)=Q_{Z B A 22}(0)=Q_{B}(0)=0$ where:

$R_{0}(t)$ - probability function for full functionality of the system $S_{P Z}$;

$Q_{Z B A I}(t), Q_{Z B A 2}(t), Q_{Z B A 1 I}(t), Q_{Z B A 12}(t)$ - probability function related to the system in individual safety hazard conditions;

$Q_{B}(t)$ - probability function related to the system in a safety deficit condition $S_{B}$;

$\lambda_{C S P}+\lambda_{S A}-$ intensity of transitions from the full functionality condition $S_{P Z}$ to the safety deficit condition $S_{B}$;

$\mu_{C S P}+\mu_{S A}-$ intensities of transition from the safety deficit condition $S_{B}$ to the full functionality condition $S_{P Z}$;

$\lambda_{1}, \lambda_{11, \ldots}-$ intensities of transitions from the full functionality condition $S_{P Z}$ or from the safety hazard condition $S_{Z B A l}, S_{Z B A 2}$ or from the safety deficit condition $S_{Z B}-$ as denoted in Fig. 6;

$\mu_{1}, \mu_{11, \ldots}-$ intensities of transitions from the safety hazard condition $S_{Z B}$ to the full functionality condition $S_{P Z}$, or from the safety deficit condition $Q_{B}$ to the safety hazard condition - according to designations in Fig. 6.

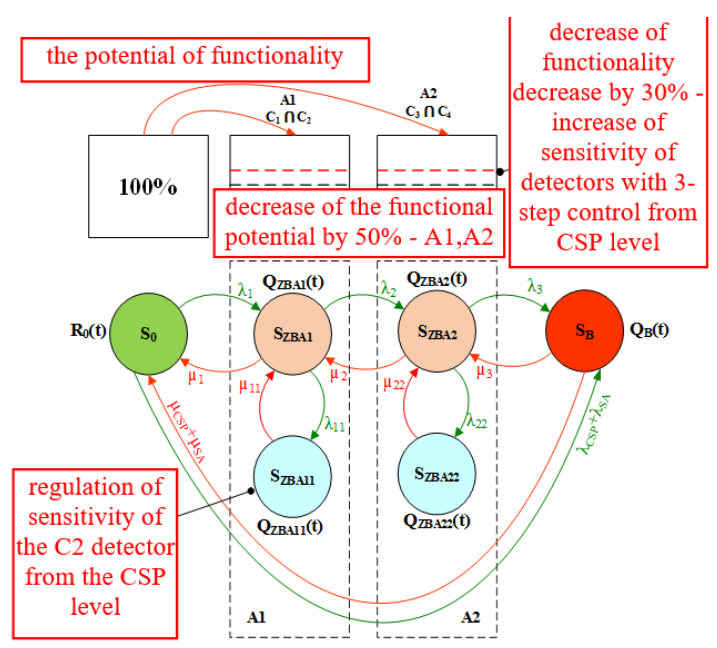

Fig. 6. Relationships within a concentrated FFS with alarm control panel (CSP), a loop-type surveillance line equipped with fire sensors operating in a coinciding system (two-sensor coincidence), and with a signalling line with a sound signalling device, where A1 is the coinciding system I, and A2 is the coinciding system II

By calculating the linear equation system, we obtain the probability of the system being in specific conditions (calculations for the selected $R_{0}(t)$ FFS - (3) state only are presented because of the complexity of the equations in question). 


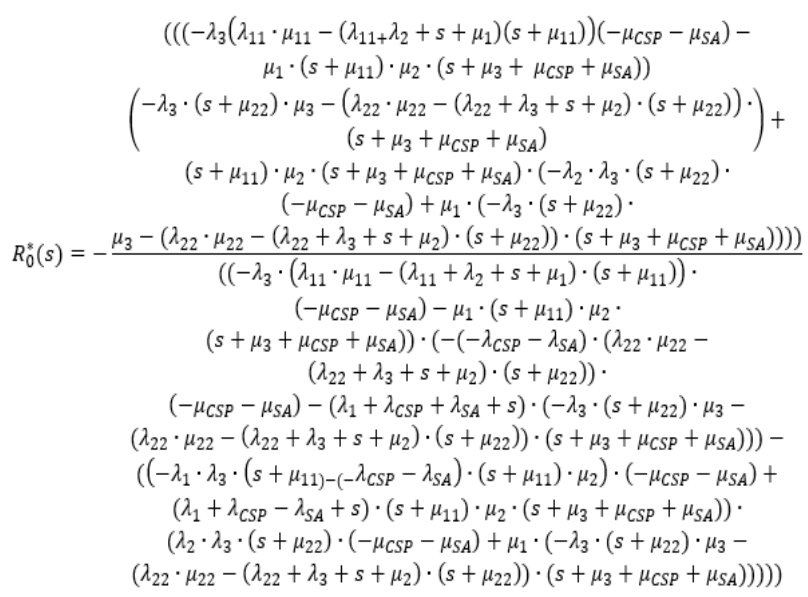

\section{OPERATIONAL SIMULATION OF A SELECTED FIRE SIGNALLING STATION}

The analysis of the FFS operation process was carried out for $\mathrm{n}=20$ different systems. The structure of the tested fire alarm systems corresponded to representative devices used for fire protection of transport facilities. All the mentioned fire alarm systems were operated in similar environmental conditions (temperature, humidity, pressure, etc.) in transport building facilities. Due to the importance of the FFS in ensuring safety in the transport process, "service teams" involved in the renewal process were available within 2 hours of reporting the failure by the persons supervising the operation (for $n=15$ FFS). Other systems ( $n=$ 5) had an extended response time to reporting a failure to 4 hours due to the supervision of transport facilities - buildings that do not directly threaten the passenger transport process (e.g. warehouses, sheds, etc.). In $n=20$ considered FFSs there are all devices that are applicable in the fire protection of transport objects (e.g. detectors, ROPs - manual call point, control modules, adapters, fire alarm control panels, etc.). In order to compile FFS operational statistics, all occurring damages and repairs were assigned to individual groups of corresponding devices. Individual groups of devices form an entire fire alarm system with various functional structures implementing a fire detection process. Detectors are the most important group of devices that are responsible for detecting a fire in the operational process. In this group of devices, during the research, there were essentially the detectors from three main manufacturers (POLON-ALFA, Bosch, Schrack) $[3,8,13,17,23,24]$. The technical parameters of the detectors (e.g. power supply, operating temperature, permissible changes in supply voltage, etc.) are the same for all manufacturers $[4,5,6,9,15,18,21]$. The maximum values of repairs (renovations) and damages that occurred in $n=20$ FFSs were taken for calculations of operational parameters. Adoption of the maximum repair times for the tested $n=20$ FFSs result from the reaction time of the operator supervising the operation process, technical capabilities of service teams (availability of equipment for replacement), location of damage, replacement time e.g. of a detector. Adopting the value of the maximum FFS repair times means that during this time the system may be out of order or partially functional (e.g. switching off a given detection line where damage occurs). FFS strives to reduce repair times by using various technical solutions (e.g. redundancy), where the repair process can be carried out during the operation of the entire system $[6,7,9,12,14,19,20,23]$. All FFSs were equipped with synoptic boards, where operators supervising the operation process have an imaging of the place (detection zone or room number) where the damage occurs. In some FFS solutions $(n=4)$, additional indicators of a detector operation were used, which are installed in corridors, in front of the room entrances. Activation of the indicator located above the entrance to a given room (matrix of red LEDs in a white casing) makes it possible to determine from a large distance in which room a fire or detector failure occurred.

For $n=4$ FFSs the following technical and fire protection installations were connected:

- gravity smoke removal systems for - staircases,

- access control system,

- fire dampers in the household mechanical ventilation system and gas valve,

- air handling units and mechanical ventilation fans.

In Figure 7, presents condition migration concentrated FSS with a loop-type surveillance line provided with fire sensors operating in a coinciding system (2-sensor coincidence), and a signal line with a sound signalling device.

Table 1. FFS parameters for time $\mathrm{t}=8760[\mathrm{~h}]-$ a concentrated system with a loop-type line with coinciding sensors.

\begin{tabular}{|c|c|c|c|c|c|}
\hline Condition & $\begin{array}{c}\text { Initial } \\
\text { probability }\end{array}$ & $\begin{array}{c}\text { Average } \\
\text { probability }\end{array}$ & $\begin{array}{c}\text { Readiness for time } \\
\mathrm{t}\end{array}$ & $\begin{array}{c}\text { Intact condition } \\
\text { for time } \mathrm{t}\end{array}$ & $\begin{array}{c}\text { Time spent in the } \\
\text { condition }\end{array}$ \\
\hline $\mathrm{S}_{0}$ & 1 & 0,99999399 & 0,999993984 & 0,994544021 & 8759,947356 \\
\hline $\mathrm{S}_{\mathrm{B}}$ & 0 & $6,78876 \mathrm{E}-07$ & $6,79158 \mathrm{E}-07$ & 0,001528988 & 0,005946958 \\
\hline $\mathrm{S}_{\mathrm{ZBA} 1}$ & 0 & $4,38571 \mathrm{E}-06$ & $4,39067 \mathrm{E}-06$ & 0,003926991 & 0,03841883 \\
\hline $\mathrm{S}_{\mathrm{ZBA} 2}$ & 0 & $9,44934 \mathrm{E}-07$ & $9,46151 \mathrm{E}-07$ & 0 & 0,00827762 \\
\hline $\mathrm{S}_{\mathrm{ZBA} 11}$ & 0 & $1,5094 \mathrm{E}-11$ & $1,5124 \mathrm{E}-11$ & 0 & $1,3222 \mathrm{E}-07$ \\
\hline $\mathrm{S}_{\mathrm{ZBA} 22}$ & 0 & $3,252 \mathrm{E}-12$ & $3,259 \mathrm{E}-12$ & 0 & $2,84877 \mathrm{E}-08$ \\
\hline
\end{tabular}




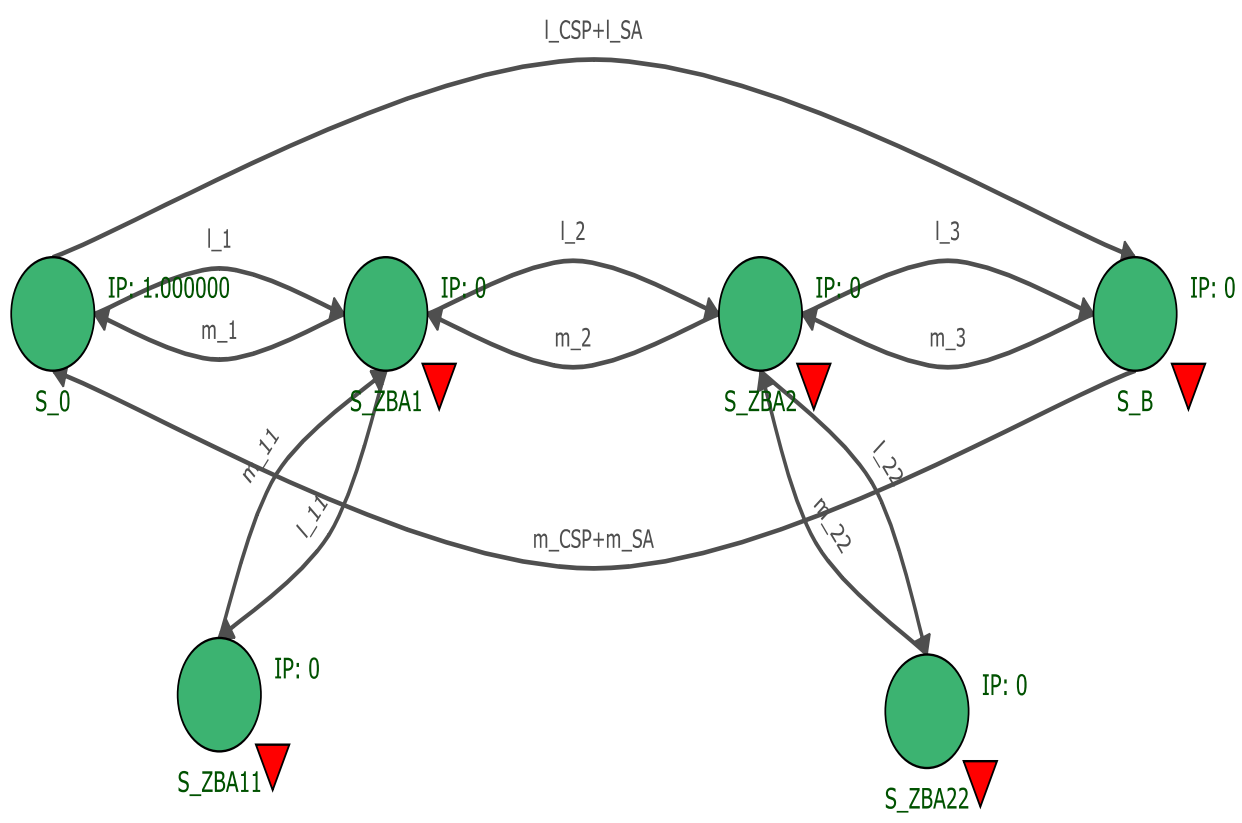

Fig. 7. Migration of potential conditions of a fire signalling station - a concentrated FSS model with a loop-type line with coinciding sensors.

Table 2. Probability matrix for transitions for individual FSS conditions for operation time $\mathrm{t}=8760[\mathrm{~h}]$.

\begin{tabular}{|c|c|c|c|c|c|c|}
\hline From $\rightarrow$ to & $\mathrm{S}_{0}$ & $\mathrm{~S}_{\mathrm{B}}$ & $\mathrm{S}_{\mathrm{ZBA} 1}$ & $\mathrm{~S}_{\mathrm{ZBA} 2}$ & $\mathrm{~S}_{\mathrm{ZBA} 11}$ & $\mathrm{~S}_{\mathrm{ZBA} 22}$ \\
\hline $\mathrm{S}_{0}$ & - & $1,7502 \mathrm{E}-07$ & $4,49514 \mathrm{E}-07$ & 0 & 0 & 0 \\
\hline $\mathrm{S}_{\mathrm{B}}$ & 0,0759 & - & 0 & 0,1818 & 0 & 0 \\
\hline $\mathrm{S}_{\mathrm{ZBA} 1}$ & 0,1305 & 0 & - & $4,49514 \mathrm{E}-07$ & $4,49514 \mathrm{E}-07$ & 0 \\
\hline $\mathrm{S}_{\mathrm{ZBA2}}$ & 0 & $2,52906 \mathrm{E}-07$ & 0,1305 & - & 0 & $4,495 \mathrm{E}-07$ \\
\hline $\mathrm{S}_{\mathrm{ZBA} 11}$ & 0 & 0 & 0,1305 & 0 & - & 0 \\
\hline $\mathrm{S}_{\mathrm{ZBA} 22}$ & 0 & 0 & 0 & 0,1305 & 0 & - \\
\hline
\end{tabular}

a)

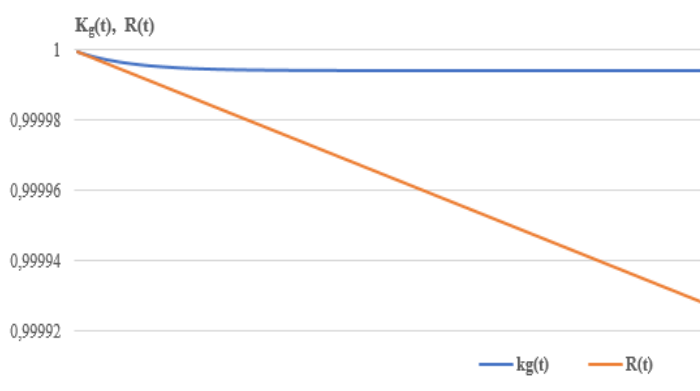

0,9999

0,99988 b)

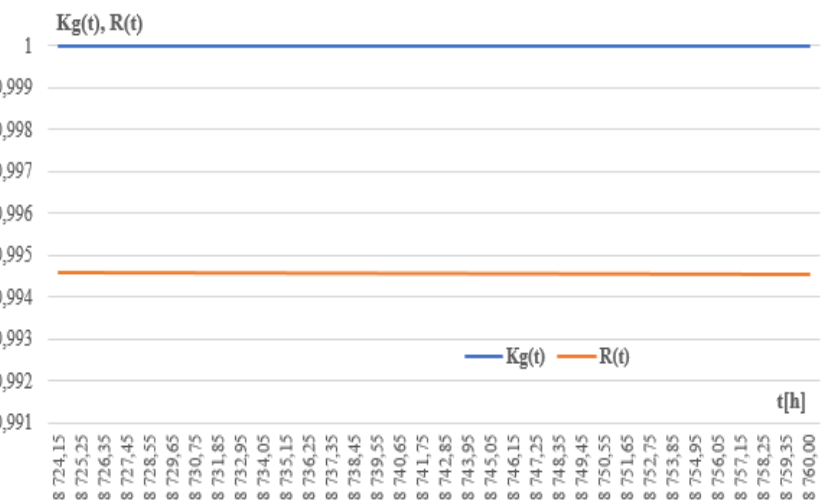

Fig. 8. Graph of the $K_{g}(t)$ and $R(t)$ functions for selected time ranges of FSS operation, a) initial system operation (time $1-106 \mathrm{~h}$ ), b) system operation time range (time $8724-8760$ ) h., where: $K_{g}(t)$ - readiness factor 
a)

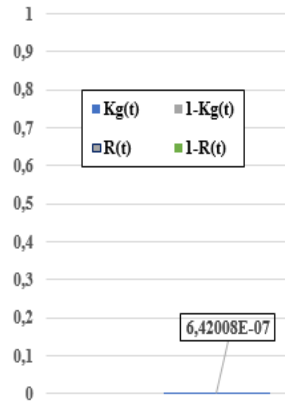

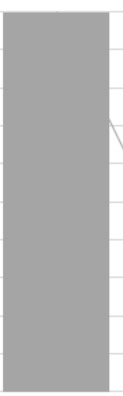
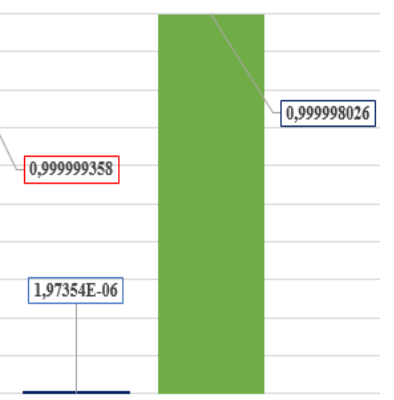

b)

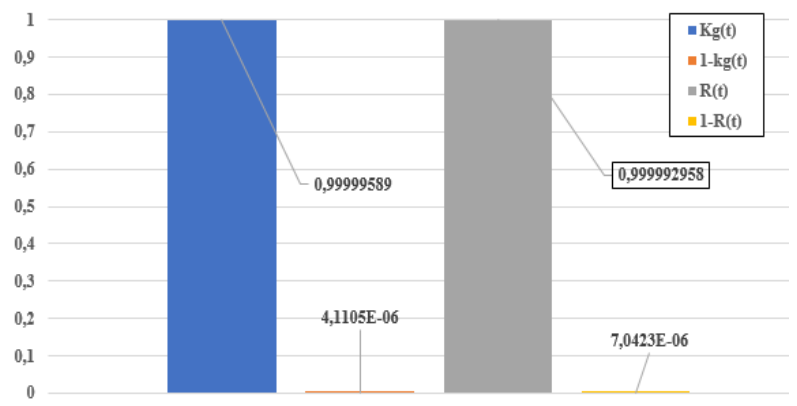

Fig. 9. Graph of the $K g(t) ; 1-K g(t) ; R(t) ; 1-R(t)$ functions for the selected FSS operation time $(\mathrm{t}=11 \mathrm{~h})$,

a) $S_{\mathrm{B}}(\mathrm{t})$ - system safety deficit condition, b) $S_{O}(t)$ - full system operation condition, where: $K g(t)$ - readiness factor

Tab. 3. FSS operation time ( $\mathrm{t}=11 \mathrm{~h})$, values: $K g(t) ; 1-K g(t) ; R(t) ; 1-R(t)$ for individual system conditions

\begin{tabular}{|c|c|c|c|c|}
\hline $\begin{array}{c}\text { SSP } \\
\text { conditions }\end{array}$ & $\mathrm{Kg}(\mathrm{t})$ for time & $1-\mathrm{Kg}(\mathrm{t})$ for time & $R(t)$ for time & $1-\mathrm{R}(\mathrm{t})$ for time \\
\hline $\mathrm{S}_{0}(\mathrm{t})$ & 0,99999589 & $4,1105 \mathrm{E}-06$ & 0,999992958 & 7,0423E-06 \\
\hline $\mathrm{S}_{\mathrm{B}}(\mathrm{t})$ & 6,42008E-07 & 0,999999358 & $1,97354 \mathrm{E}-06$ & 0,999998026 \\
\hline $\mathrm{S}_{\mathrm{ZBA} 1}(\mathrm{t})$ & $2,90929 \mathrm{E}-06$ & 0,999997091 & $5,06876 \mathrm{E}-06$ & 0,999994931 \\
\hline $\mathrm{S}_{\mathrm{ZBA} 2}(\mathrm{t})$ & 5,59191E-07 & 0,999999441 & 0 & 1 \\
\hline $\mathrm{S}_{\mathrm{ZBA} 11}(\mathrm{t})$ & $5,445 \mathrm{E}-12$ & 1 & 0 & 1 \\
\hline
\end{tabular}

Tab. 4. Determined $K g(t)$ and $R(t)$ decrease rates for the selected FSSS operation time range according to Fig. 7a).

\begin{tabular}{|c|c|c|}
\hline $\mathrm{t}=12,37624[\mathrm{~h}]$ & $\mathrm{Kg}(\mathrm{t})=0,999995685$ & $\mathrm{R}(\mathrm{t})=0,999992271$ \\
\hline $\mathrm{t}=68,48185[\mathrm{~h}]$ & $\mathrm{Kg}(\mathrm{t})=0,999993987$ & $\mathrm{R}(\mathrm{t})=0,999957232$ \\
\hline$\Delta \mathrm{t}=56,10561[\mathrm{~h}]$ & $\Delta \mathrm{Kg}(\mathrm{t})=0,000001698$ & $\Delta \mathrm{R}(\mathrm{t})=0,000035039$ \\
\hline Calculated rates & $\mathrm{S}_{\mathrm{Sk}}[1 / \mathrm{h}]=3,02635 \mathrm{E}-10$ & $\mathrm{~S}_{\mathrm{SR}}(\mathrm{t})=6,2452 \mathrm{E}-7$ \\
\hline
\end{tabular}

The values of $K g(t), R(t)$ characteristic decrease rates have been determined according to $(4-7)$ equations for a fully operational FSS.

$$
\begin{gathered}
S_{S K}=\frac{\Delta K g(t)_{p}}{\Delta t}\left[\frac{1}{h}\right] \\
S_{S K}=\frac{(0,9999956685)-(0,999993987)}{68,48185-12,37624}=3,02635 E-10\left[\frac{1}{h}\right] \\
S_{S R}=\frac{\Delta R(t)_{p}}{\Delta t}\left[\frac{1}{h}\right] \\
S_{S R}=\frac{(0,999992271)-(0,999957232)}{68,48185-12,37624}=6,2452 E-7\left[\frac{1}{h}\right]
\end{gathered}
$$

The FSS is fully operational for 8759.95 [h] tab. 1 (one year of operation was accepted in the computer simulation). The system availability factor is $K_{g}(t)=0.999993984$. The availability factor for hazard and FSS safety deficit conditions is extremely small, $10^{-6}$ to $10^{-12}$, e.g. for the $S_{Z B A 22}$ system condition - tab. 1. Fig. 7 presents a migration between potential FSS conditions - a concentrated model with a loop-type line, with coinciding sensors. At the initial time of FSS operation - Fig. 9a) we can observe a fast decrease of the $R(t)$ function for the entire FSS. The decrease rate $R(t)$ and $K_{g}(t)$ has been determined according to equations 4,6 , whilst the calculated rate values have been presented in tab. 4 .

\section{SUMMARY AND CONCLUSIONS}

This paper presents operation of a selected FFS with a concentrated structure, with a loop-type line with coinciding sensors. At the beginning of operation (after commissioning), the system displays a significant decrease of the reliability function $R(t)$ - the so called "system infancy" $[10,11,20,25]$. The decrease rate is $S_{S R}(t)$ $=6,2452 \mathrm{E}-7$. Values of the characteristics stabilise at the required level of $R(t)$ and $K_{g}(t)$ functions subsequently - during system operation - Fig. 8b) - the so called ,normal operation" [2,5,6,9,10, 11,21]. At FSS operation time of $\mathrm{t}=11$ [h], $\mathrm{R}(\mathrm{t})=$ 0,999992958 . Other $R(t)$ values for individual conditions of FSS operation are very small - see tab. 3 (for the same operation time). The $R(t)$ and $K_{g}(t)$ function decrease rates have been determined according to equations 4, 6 and presented in Tab. 4. The characteristic decrease rate is extremely small, at the level of $10^{-7}$ for $R(t)$. Use of appropriate FSS technical solutions, including redundancy and use of the safe damage rule may stop the trend of $R(t)$ and $K_{g}(t)$ function changes during the initial period of system operation $[5,8,10,13,14,18,19]$. An ideal technical system should display a zero decrease rate (including changes and sudden changes of their values) for functions $S_{S R}(t)$ and $S_{S k}(t)$.

Increasing the FFS service time reduces system reliability. The above can be used as a tool for FFS 
users to set a time limit for undertaking intervention measures while servicing. The service response time should be maximally shortened, e.g. due to the system readiness factor, and spare parts for FFSs in transport facilities should be available on site or in the service technician's warehouse. FFS service may be undertaken by an entity with the location of the headquarters (distance from the serviced object) allowing to obtain the assumed times in accordance with the calculation of the repair time. Maintenance inspections of the service should be carried out with optimal intensity, ensuring achievement of the maximum readiness index $K_{g}(t)$. The values of particular probabilities of the system staying in the distinguished states depend on the configuration of detection lines and detectors on loops or detection lines.

\section{References}

1. Chan PY. Littlewood B., Snell J. Recalibrating software reliability models. IEEE Trans. Softw. Eng.. 1990; 16: 458-470.

2. Chen S, Ho T, Mao B. Maintenance schedule optimisation for a railway power supply system. International Journal of Production Research 2013;51(16):4896-4910.

3. Klimczak T, Paś J. Reliability and operating analysis of transmission of alarm signals of distributed fire signaling system. Journal of KONBIN. 2019; 49: 165-174.

https://doi.org/10.2478/jok-2019-0009

4. Kušnerová $M$, Palková $Z$, Harničárová $M$, Ionitescu S. Heat penetration parameters of newly proposed thermal insulating concretes from the viewpoint of power consumption and environmental impacts, Scientific Papers. Series E. Land Reclamation, Earth Observation \& Surveying, Environmental Engineering; Vol. VII; 2018.

5. Paś J, Rosiński A. Selected issues regarding the reliability-operational assessment of electronic transport systems with regard to electromagnetic interference. Eksploatacja i Niezawodnosc Maintenance and Reliability. 2017;19(3):375381. https://doi.org/10.17531/ein.2017.3.8

6. Manzini R. Regattieri A, Pham H, Ferrari E. Maintenance for Industrial Systems, SpringerVerlag, London 2010.

7. Laskowski D, Łubkowski P, Pawlak E, Stańczyk P. Anthropotechnical systems reliability. In: the monograph „Safety and Reliability: Methodology and Applications Proceedings of the European Safety and Reliability Conference ESREL 2014", editors: Nowakowski T., Młyńczak M., JodejkoPietruczuk A. \&Werbińska-Wojciechowska S. CRC Press/Balkema, London, 2015: 399-407.

8. Klimczak T, Paś J. Analysis of reliability structures for fire signaling systems in the field of fire safety and hardware requirements.
Journal of KONBIN. 2018;46:191-214.

https://doi.org/10.2478/jok-2018-0030

9. Levitin G. The Universal Generating Function in Reliability Analysis and Optimization. Springer-Verlag, London 2005.

10. Fries R, Chowdhury M, Brummond J. Transportation infrastructure security utilizing inteligent transportation systems. John Wiley \& Sons, New Jersey 2009.

11. Duer S, Scaticailov S, Paś J, Duer R, Bernatowicz D. Taking decisions in the diagnostic intelligent systems on the basis information from an artificial neural network, 22nd International Conference on Innovative Manufacturing Engineering and Energy IManE\&E 2018, MATEC Web of Conferences 2018;178:1-6.

12. Jarmakiewicz J, Maślanka K, Parobczak K. Evaluation of the cyber security provision system for critical infrastructure. Journal of Telecommunications and Information Technology. 2015;4:22-29.

13. Klimczak T, Paś J. Reliability and operating analysis of transmission of alarm signals of distributed fire signaling system. Journal of KONBIN 2019;49:165-174 https://doi.org/10.2478/jok-2019-0009,

14. Skorupski J, Uchroński P. A fuzzy reasoning system for evaluating the efficiency of cabin luggage screening at airports. Transportation Research Part C - Emerging Technologies, 2015;54: 157-175. https://doi.org/10.1016/j.trc.2015.03.017

15. Yang L, Yan X. Design for reliability of solid state lighting products. In: Solid State Lighting Reliability, eds: van Driel W., Fan X. Solid State Lighting Technology and Application Series, vol 1. Springer New York, 2013:497556.

16. Siergiejczyk M, Paś J, Rosiński A. Issue of reliability-exploitation evaluation of electronic transport systems used in the railway environment with consideration of electromagnetic interference. IET Intelligent Transport Systems. 2016:567-593. https://doi.org/10.1049/iet-its.2015.0183,

17. Klimczak T, Paś J. Reliability-operational analysis of fixed gas fire extinguishing equipment integrated with fire signaling systems. Biuletyn WAT. 2019; LXVIII(2): 189200.

18. Billinton R, Allan RN. Reliability evaluation of power systems, New York, Plenum Press, 1996.

19. Nakagawa T. Advanced reliability models and maintenance policies. Springer-Verlag, London 2008.

20. Moubray J. Reliability - centered maintenance. Industrial Press, New York 1997.

21. Paś J, Rosiński A, Szulim M, Łukasiak J. Modelling the safety levels of ICT equipment exposed to strong electromagnetic pulses. 
International Conference on Dependability and Complex Systems. 2019; 987; 393-401.

22. Kołowrocki K, Soszyńska-Budny J. Reliability and safety of complex technical systems and processes. Springer, London 2011.

23. Klimczak T, Paś J. Selected issues of the reliability and operational assessment of a fire alarm system. Eksploatacja i Niezawodnosc Maintenance and Reliability. 2019;21(4): 553561 http://dx.doi.org/10.17531/ein.2019.4

24. Klimczak T, Paś J. Reliability-operational analysis of fixed gas fire extinguishing equipment integrated with fire signaling systems. Biuletyn WAT. 2019; LXVIII(2): 189200.

25. Sierpiński G, Staniek M. Platform to support the implementation of electromobility in smart cities based on ICT applications - concept for an electric travelling project. Scientific Journal of Silesian University of Technology, Series Transport 2018; 100:181-189. https://doi.org/10.20858/sjsutst.2018.100.15.

26. Turoń K, Czech P, Tóth J. Safety and security aspects in shared mobility systems. Scientific Journal of Silesian University of Technology, Series Transport 2019;104:169-175. https://doi.org/10.20858/sjsutst.2019.104.15.

Received 2019-07-08

Accepted 2019-10-11

Available online 2019-10-15

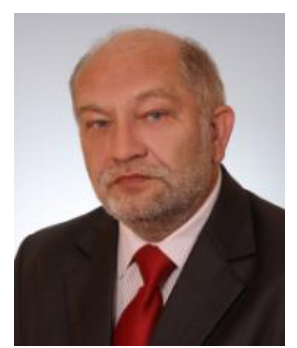

$\overline{\text { Jacek PAŚ Associate }}$ Professor Ph.D. D.Sc. Eng. scientific interests (electromagnetic compatibility, analog circuits, reliability, low frequency noise, exploitation, projecting, diagnostics) are problems connected with comprehended wide of the safety both for stationary as well as for movable objects. He is the author of three books and more than 200 articles. His research interests include also environmental studies of electromagnetic the range at low frequencies at (electrosmog).

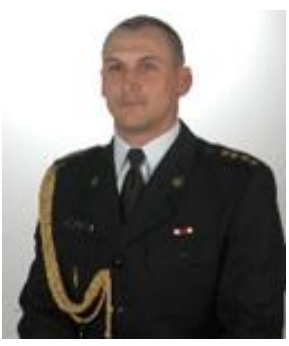

Tomasz KLIMCZAK, junior brigadier, Ph.D. Eng., is an officer of the State Fire Service, who serves permanently at The Main School of Fire Service in Warsaw. He designs fire alarm systems, fixed gas fireextinguishing systems and other fire protection equipment. He conducts training for fixed gas fire-extinguishing system designers at the Research Institute of CNBOP-PIB in Józefów. He has written several scientific articles concerning issues related to fire alarm systems, fire scenarios and fire techniques 